Jurnal Teknik Komputer AMIK BSI

Volume VI No.1 Januari 2020

P-ISSN 2442-2436, E-ISSN: 2550-0120

Akreditasi Ristekdikti, No: 21/E/KPT/2018

DOI: $10.31294 / j$ tk.v4i2

\title{
Penerapan Logika Fuzzy Metode Sugeno Untuk Optimalisasi Nilai Ekspor Ikan Tuna Hs 160414 Ke Italia
}

\author{
Luthfia Rohimah $^{1}$, Sinta Rukiastiandari ${ }^{2}$, Juarni Siregar ${ }^{3}$ \\ ${ }^{1,2}$ Universitas Bina Sarana Informatika \\ 1e-mail: luthfia.lhm@bsi.ac.id \\ 2e-mail: sinta.sru@bsi.ac.id \\ ${ }^{3}$ STMIK Nusa Mandiri \\ e-mail: juarni.jsr@bsi.ac.id

\begin{tabular}{ccc} 
Diterima & Direvisi & Disetujui \\
$09-10-2019$ & $20-12-2019$ & $10-01-2020$ \\
\hline
\end{tabular}

\begin{abstract}
Abstrak - Untuk mendanai pembangunan yang sedang berjalan saat ini Negara membutuhkan pendapatan dari berbagai sumber seperti pendapatan dari ekspor. Ekspor adalah kegiatan pengiriman barang ke luar negeri di mana kegiatan tersebut akan menghasilkan nilai. Dan nilai ekspor Indonesia yang cukup tinggi berasal dari ekspor nonmigas, salah satunya adalah ekspor tuna olahan 160414. Salah satu negara tujuan untuk ekspor tuna olahan yang cukup tinggi adalah Italia. Tujuan dari penelitian ini adalah untuk mengetahui metode terbaik untuk memprediksi nilai ekspor tuna olahan ke Italia dalam penerapan logika fuzzy untuk mengoptimalkan nilai ekspor. Hasil penelitian menunjukkan bahwa metode Sugeno adalah metode yang baik. Metode Sugeno memiliki hasil yang cukup dekat dengan hasil aktual dengan tingkat kesalahan $41 \%$, sehingga metode Sugeno dapat digunakan sebagai metode yang direkomendasikan dalam memprediksi jumlah optimal ekspor 160414 HS Indonesia ke Italia.
\end{abstract}

Kata Kunci: Sugeno, optimize, export, import.

Abstract-To fund the ongoing development at this time the State requires income from various sources such as income from exports. Export is an activity of sending goods abroad where the activity will produce value. And Indonesia's export value which is quite high comes from non-oil and gas exports, one of which is the export of processed tuna 160414. One of the destination countries for the export of processed tuna which is quite high is Italy. The purpose of this study is to find out the best method for predicting the value of processed tuna exports to Italy in the application of fuzzy logic in order to optimize the value of exports. The results showed that the Sugeno method is a good method. The Sugeno method has results that are quite close to the actual results with an error rate of $41 \%$, so the Sugeno method can be used as a recommended method in predicting the optimal amount of Indonesia's 160414 HS exports to Italy.

Keywords: Sugeno, optimize, export, import.

\section{PENDAHULUAN}

Secara historis, pertumbuhan ekonomi di negara-negara maju sangat didukung oleh pertumbuhan ekspor. Ekspor merupakan penjualan produk-produk baik barang maupun jasa dari dalam ke luar negeri (Sedyaningrum, Suhadak, \& Nuzula, 2016). Di Indonesia Ekspor merupakan salah satu pendapatan Negara yang cukup besar nilainya.

Setiap tahun pemerintah menetapkan target pertumbuhan ekspor dalam mendukung pertumbuhan ekonomi dan penciptaan lapangan kerja. Dalam periode 2005-2009 pemerintah dengan program "Rencana Pembangunan Jangka Menengah
Nasional" menargetkan peningkatan ekspor dari 5,5\% pada tahun 2005 menjadi 8,7\% pada tahun 2009.

Di Indonesia terdapat dua komiditi ekspor, yaitu komiditi migas dan komiditi non migas. Namun semenjak tahun 1990 ekspor migas mulai menunjukan trend yang menurun seperti yang terlihat pada tabel 1. Menurunnya ekspor migas memberi isyarat bagi pemerintah mengambil langkah kebijakan meningkatkan ekspor non migas agar pendapatan negara tetap terus bertambah. 
Tabel 1. Nilai Ekspor Indonesia 2014

(Nilai : juta USD\$)

\begin{tabular}{|c|c|c|c|}
\hline Bulan & Total & Migas & Non Migas \\
\hline Desember & $14.621,31$ & $2.353,33$ & $12.267,97$ \\
\hline November & $13.616,20$ & $2.106,90$ & $11.509,30$ \\
\hline Oktober & $15.348,97$ & $2.469,42$ & $12.879,55$ \\
\hline September & $15.275,85$ & $2.622,61$ & $12.653,23$ \\
\hline Agustus & $14.481,66$ & $2.598,17$ & $11.883,47$ \\
\hline Juli & $14.124,13$ & $2.496,32$ & $11.627,81$ \\
\hline Juni & $15.409,45$ & $2.785,96$ & $12.623,49$ \\
\hline Mei & $14.823,60$ & $2.375,69$ & $12.447,91$ \\
\hline April & $14.292,47$ & $2.651,38$ & $11.641,10$ \\
\hline Maret & $15.192,62$ & $2.641,29$ & $12.551,33$ \\
\hline
\end{tabular}

Sumber : www.kemendag.go.id

Agar nilai ekspor non migas bias terus meningkat maka kita harus mengetahui produk produk apa saja yang mempunyai nilai unggul dan Negara mana yang akan menjadi Negara tujuan produk tersebut.. Selain itu, (Rachman, 2013) menambahkan bahwa untuk meningkatkan jumlah ekspor dapat dilakukan dengan mengkaji permasalahan yang muncul sehingga dapat ditindaklanjuti dengan kebijakan yang sesuai.

Arah kebijakan GBHN dalam program nasional pengembangan ekspor seperti yang dikutip oleh (Mastur, 2006) adalah melakukan secara proaktif negosiasi dengan kerja sama bilateral dan multilateral dalam rangka meningkatkan volume dan nilai ekspor.

Dalam kerjasama bilateral, Italia merupakan negara mitra dagang yang strategis bagi Indonesia.

Produk ekspor non-migas utama Indonesia ke Italia meliputi: (1) copper ores and concentrates; (2) coal; briquettes, ovoids and similar solid fuels manufactured from coal; (3) nickel mattes; (4) natural rubber, balata, guttapercha; (5) refined copper and copper alloys, unwrought; (6) plywood, veneered panels and similar laminated wood; (7) paper and paperboard, uncoated, for writing; (8) insulated wire, cable and other insulated electrical conductors; (9) crustaceans, live, fresh, chilled, frozen; dan (10) unwrought aluminium. (Situs Kemendag).

Ikan tuna merupakan komoditas ikan yang paling utama didunia.produk ini menempati urutan ketiga dalam komoditas internasional. Produk utama olahan ikan tuna dalam bentuk ikan kaleh atau konsumsi langsung.

Indonesia mulai berkembang menjadi produsen ikan tuna smenjak dua puluh tahun terakhir. Negara Asia lainya yang merupakan produsen ikan tuna antara lain : Thailand, Filipina, dan Papua New Guine. Keunggulan Indonesia dibandingkan dengan negara Asia lainya adalah Indonesia mempunyai perairan yang luas dimana Indonesia tidak memerlukan impor bahan baku untuk olahan ikan tuna.
Amerika dan Eropa merupakan pengimpor ikan tuna terbesar didunia. Negara - negara Eropa itu sendiri antara lain : Inggris, Perancis, Jerman, Italia, Belanda, Spanyol, dan lainya. Dan Italia sendiri merupakan pangsa pasar utama dari produk olahan ikan tuna.

Italia merupakan negara pengimpor ikan tuna olahan karena ekspor Italia hanya $1 \%$ dari nilai impornya (ekspor US\$ 127,491 dan impor US\$ 28,878 pada bulan Juli tahun 2018). Didukung dengan trend impor Italia yang masih mengindikasikan pertumbuhan, maka dapat disimpulkan bahwa pada tahun yang akan datang permintaan (impor) akan produk ini di Italia akan semakin meningkat. Oleh karena itu, Indonesia harus mampu memaksimalkan nilai ekspor sepatu ke Jepang sebagai komoditi nonmigas untuk menutupi kekurangan dari ekspor komoditi migas yang melemah. Namun, upaya tersebut tentu memerlukan metode yang tepat.

Ada banyak metode dan teknik yang dapat dilakukan untuk menganalisis pengoptimalan ekspor, namun Indonesia harus mampu memilih dan menggunakan metode yang tepat untuk upaya pengoptimalan jumlah ekspor ini dimana permasalahan yang timbul seringkali tidak pasti. Salah satu metode yang dapat digunakan adalah metode logika fuzzy. Seperti yang dikutip dari (Komariyah, Yunus, \& Rodiyansyah, 2016), fuzzy artinya kabur atau samar, sehingga yang dimaksud dengan logika fuzzy adalah logika yang memiliki nilai kekaburan atau kesamaran antara benar atau salah.

Dipilihnya logika fuzzy dalam menganalisis pengoptimalan ekspor antara lain logika fuzzy mudah di mengerti, fleksibel, memiliki toleransi terhadap data - data yang tidak pasti, dan logika fuzzy menggunakan bahasa alami. Hal ini juga disampaikan oleh (Wibowo, 2015) bahwa logika fuzzy merupakan salah satu metode untuk melakukan analisis sitem yang mengandung ketidakpastian.

Penalaran metode Sugeno hampir sama dengan penalaran Mamdani, hanya saja output system tidak berupa himpunan fuzzy melainkan berupa konstanta atau persamaan linear (Iswari \& Wahid, 2005). Metode Sugeno adalah metode inferensi fuzzy untuk aturan yang direpresentasikan dalam bentuk IF - THEN dimana output sistem tidak dalam bentuk himpunan fuzzy tetapi dalam bentuk konstanta atau persamaan linier (Wachdani, Abidin, \& Yaqin, 2012). Metode ini diperkenalkan oleh Takagi-Sugeno Kang pada tahun 1985.

Berdasarkan latar belakang yang telah diuraikan diatas, maka permasalahan yang dibahas dalam penelitian ini adalah mencari nilai yang paling tepat untuk digunakan dalam pengoptimalan nilai ekspor ikan tuna olahan HS 160414 ke Italia. Metode yang digunakan dalam penelitian ini adalah metode Sugeno dalam sistem logika fuzzy. 


\section{Pengertian Logika Fuzzy}

Logika Fuzzy merupakan salah satu komponen pembentuk soft computing. Logika fuzzy pertama kali diperkenalkan oleh Prof. Lotfi A. Zadeh pada tahun 1965. Dasar logika fuzzy adalah teori himpunan fuzzy. Pada teori himpunan fuzzy, peranan derajat keanggotaan sebagai penentu keberadaan elemen dalam suatu himpunan sangatlah penting. Nilai keanggotaan atau derajat keanggotaan atau membership function menjadi ciri utama dari penalaran dengan logika fuzzy tersebut (Kusumadewi \& Purnomo, 2010).

Logika fuzzy digunakan sebagai suatu cara untuk memetakan permasalahan dari input menuju ke output yang diharapkan. Logika fuzzy dapat dianggap sebagai kotak hitam yang menghubungkan antara ruang input menuju ruang output, Gelley (2000) dalam Sri Kusumadewi dan Hari Purnomo (2010,p.2).

\section{METODOLOGI PENELITIAN}

Menjelaskan kronologis penelitian, termasuk desain penelitian, prosedur penelitian (dalam bentuk algoritma, Pseudocode atau lainnya), bagaimana untuk menguji dan akuisisi data. Deskripsi dari

program penelitian harus didukung referensi, sehingga penjelasan tersebut dapat diterima secara ilmiah. Jenis penelitian yang digunakan dalam penelitian ini adalah model eksperimen.

Penelitian eksperimen ini menggunakan algoritma fuzzy dengan menggunakan metode Sugeno untuk optimalisasi nilai ekspor ikan tuna ke Italia.

Jenis data yang digunakan dalam penelitian ini adalah data sekunder yang diperoleh penulis dari www.trademap.org dimana menyediakan data-data tentang jumlah nilai impor ikan tuna negara Italia.

\section{HASIL DAN PEMBAHASAN}

Untuk menghasilkan output yang di inginkan, yaitu informasi mengenai nilai ekspor maximum ikan tuna HS 160414 ke Italia, maka di perlukan beberapa langkah, yaitu :

1.Pembentukan himpunan fuzzy

2.Pembentukan aturan-aturan

3.Penentuan komposisi aturan

4.Penegasan (defuzzy)

Pada pembentukan himpunan fuzzy untuk kasus prediksi nilai maximum ekspor ikan tuna olahan HS 160414 ke Italia, terdapat 2 input dan output. Variabel input terdiri dari jumlah impor ikan tuna olahan HS 160414 Italia dan jumlah ekspor ikan tuna olahan HS 160414 Indonesia ke seluruh dunia, sedangkan variabel output terdiri dari jumlah ekspor ikan tuna olahan HS 160414 Indonesia ke Italia.
Tabel 2. Himpunan Semesta

\begin{tabular}{|l|l|l|l|}
\hline Fungsi & Variabel & $\begin{array}{l}\text { Semesta } \\
\text { Pembicaraan }\end{array}$ & Keterangan \\
\hline \multirow{5}{*}{ Input } & $\begin{array}{l}\text { Impor } \\
\text { HS } \\
160414 \\
\text { Italia }\end{array}$ & {$[46-114]$} & $\begin{array}{l}\text { Jumlah } \\
\text { permintaan impor } \\
\text { sepatu kulit HS } \\
160414 \quad \text { Italia } \\
\text { dalam satuan US } \\
\text { Dollar thousand }\end{array}$ \\
\cline { 2 - 4 } & $\begin{array}{l}\text { Total } \\
\text { Ekspor } \\
\text { HS } \\
160414 \\
\text { Indonesia }\end{array}$ & {$[20-40]$} & $\begin{array}{l}\text { Jumlah Total } \\
\text { ekspori sepatu } \\
\text { kulit HS 160414 } \\
\text { Indonesia yang di } \\
\text { ekspor dalam } \\
\text { satuan dollar }\end{array}$ \\
\hline \multirow{5}{*}{ Output } & $\begin{array}{l}\text { HS } \\
\text { I60414 } \\
\text { Indonesia } \\
\text { ke Itali }\end{array}$ & {$[2,8-6]$} & $\begin{array}{l}\text { Jumlah ekspor } \\
\text { sepatu kulit HS } \\
\text { 160414 Indonesia } \\
\text { ke Italia dalam } \\
\text { satuan US Dollar } \\
\text { thousand }\end{array}$ \\
\hline
\end{tabular}

\begin{tabular}{|c|c|c|c|}
\hline Aturan & $\begin{array}{c}\text { Jumlah } \\
\text { impor HS } \\
\mathbf{6 4 0 3} \text { Jepang }\end{array}$ & $\begin{array}{c}\text { Jumlah } \\
\text { ekspor HS } \\
\mathbf{6 4 0 3}\end{array}$ & $\begin{array}{c}\text { JUmlah ekspor } \\
\text { HS 160414 }\end{array}$ \\
\hline R1 & Turun & Naik & Turun \\
\hline R2 & Turun & Naik & Naik \\
\hline R3 & Turun & Turun & Turun \\
\hline R4 & Turun & Turun & Naik \\
\hline R5 & Naik & Naik & Turun \\
\hline R6 & Naik & Naik & Naik \\
\hline R7 & Naik & Turun & Turun \\
\hline R8 & Naik & Turun & Naik \\
\hline
\end{tabular}

Tabel 3. Pembentukan Aturan - Aturan

Setelah mengidentifikasi variabel - variabel yang terdapat di dalam himpunan fuzzy, langkah selanjutnya menentukan nilai linguistik pada masing - masing variabel. Untuk variabel input jumlah impor ikan tuna olahan HS 160414 Italia terdapat 2 nilai linguistik, yaitu Naik dan Turun, sedangkan untuk variabel input jumlah ekspor ikan tuna olahan HS 160414 Indonesia ke eluruh dunia terdapat 2 nilai linguistik, yaitu naik dan turun. Dan untuk variabel output jumlah ekspor ikan tuna olahan HS 160414 Indonesia ke Italia terdapat 2 nilai linguistik, yaitu Naik dan Turun. 
Setelah membuat himpunan fuzzy beserta nilai linguistiknnya, langkah selanjutnya adalah membentuk aturan - aturan, dimana dalam penelitian ini atutan yang digunakan adalah aturan MIN. di penelitian ini terdapat 4 buah aturan, yaitu [R1] IF JII Turun AND JEI Naik, THEN JeII Naik [R2] IF JII Turun AND JEI Turun, THEN JeII Turun

[R3] IF JII Naik AND JEI Naik, THEN JeII Naik [R4] IF JII Naik AND JEI Turun, THEN JeII Naik.

Langkah selanjutnya setelah melakukan pembentukan aturan adalah membuat komposisi aturan. Dimana dalam penelitian ini komposisi aturan yang digunakan adalah metode MAX. Setelah melakukan komposisi aturan langkah selanjutnya adalah melakukan defuzzyfikasi, proses ini berfungsi untuk merubah nilai output yang semula bernilai linguistic menjadi nilai tegas. Untuk metode Sugeno, menggunakan pada tahap fuzzyfikasi menggunakan rumus :

$$
Z^{*}=\frac{\sum_{i=1}^{n} d_{i} U_{\widetilde{A}_{i}}\left(d_{i}\right)}{\sum_{i=1}^{n} U_{\widetilde{A_{l}}}\left(d_{i}\right)}
$$

Berikut adalah cara pemecahan masalah menggunakan metode Sugeno :

1. Membuka lembar kerja Matlab

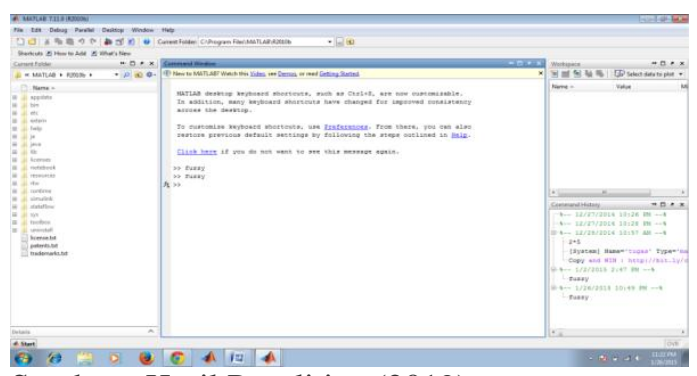

Sumber : Hasil Penelitian (2019)

Gambar 1. Tampilan awal matlab

2. Pada jendela kerja ketikan "fuzzy", maka akan muncul jendela berikut ini :

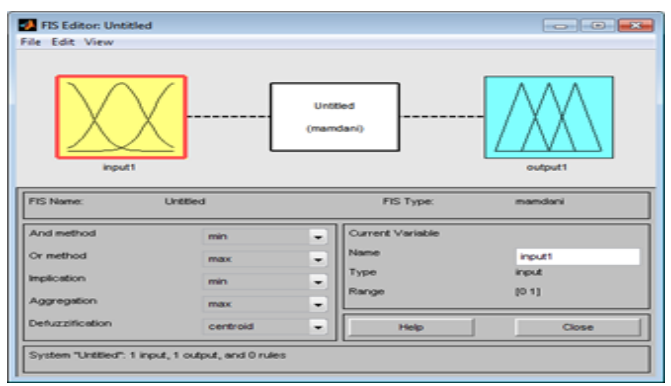

Sumber : Hasil Penelitian (2019)

Gambar 2. Tampilan pemberian input dan output

3. Langkah selanjutnya adalah mengtur fungsi dari keanggotaan input.

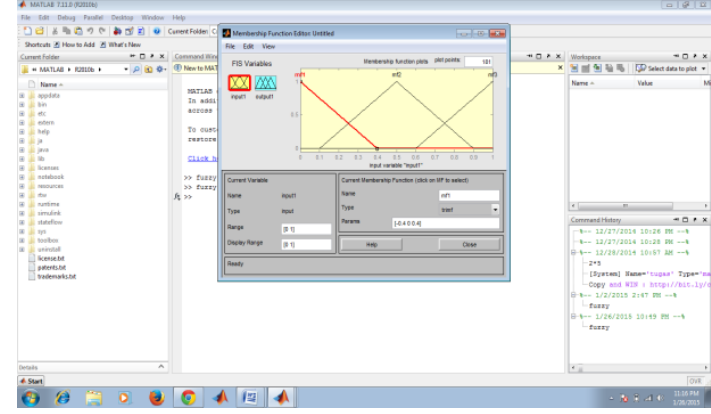

Sumber : Hasil Penelitian (2019)

Gambar 3. Tampilan pemberian fungsi keanggotaan inputan

4. Mengatur fungsi keanggotaan dari output

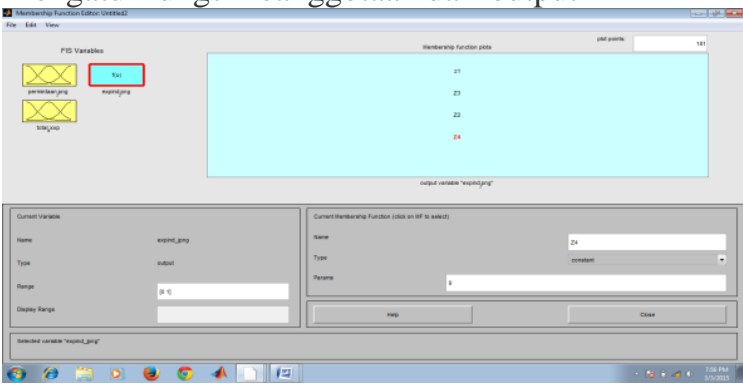

Sumber : Hasil Penelitian (2019)

Gambar 4. Tampilan fungsi keanggotaan output

5. Membentuk aturan dan logika

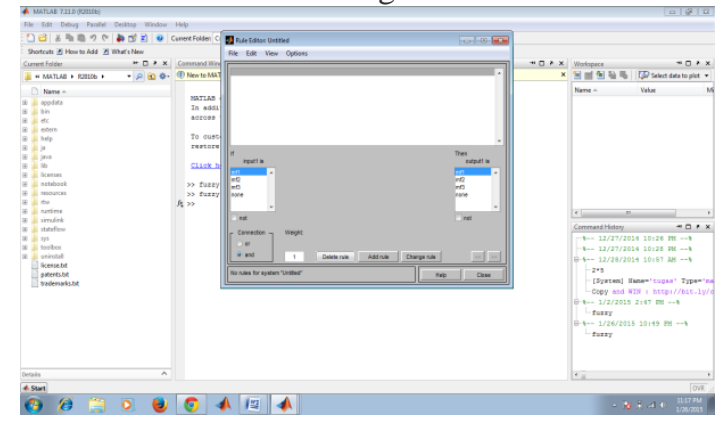

Sumber : Hasil Penelitian (2019)

Gambar 5. Tampilan membentuk aturan

6. Langkah terakhir dari proses pengujian ini adalah melihat apakah hasil sesuai dengan yang diharapkan, yaitu dengan cara memilih menu rule view pada lembar kerja.

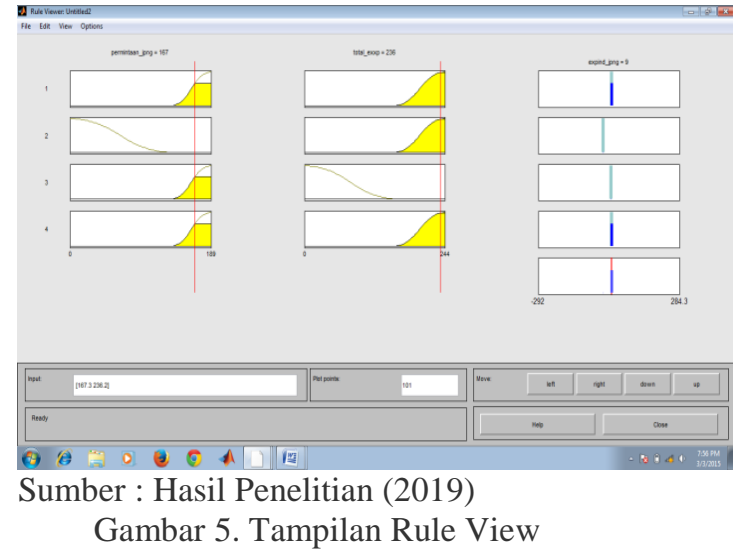


Tabel 4. Hasil Perhitungan dengan Menggunakan Sugeno,

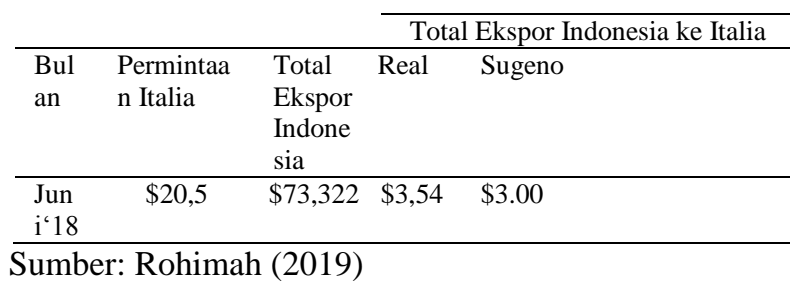

Dari data pada Tabel 3. dapat dilihat bahwa metode yang Sugeno dapat digunakan karena mendapatkan hasil yang selisihnya kecil dengan data yang ada, dimana jumlah total ekspor HS 160414 Indonesia ke Italia sebenarnya adalah \$ 3.542 sedangkan hasil dari perhitungan dengan Sugeno adalah $\$ 3.000$, dengan nilai errornya adalah $15 \%$.

Data berikut adalah data penghitungan pada Tabel 1. dengan cara yang sama, yaitu dengan metode Sugeno .

Tabel 5. Hasil Optimalisasi Ekspor HS 160414 dengan Sugeno.

\begin{tabular}{|c|c|c|c|c|}
\hline $\begin{array}{c}\text { BULA } \\
\mathbf{N}\end{array}$ & $\begin{array}{c}\text { Expor HS } \\
160414 \\
\text { Indonesia } \\
\text { ke dunia }\end{array}$ & $\begin{array}{c}\text { Impor } \\
\text { HS } \\
160414 \\
\text { Italia }\end{array}$ & $\begin{array}{c}\text { Expor } \\
\text { HS } \\
160414 \\
\text { Indonesi } \\
\text { a ke } \\
\text { Italia }\end{array}$ & $\begin{array}{c}\text { Hasil } \\
\text { Ekspor } \\
\text { HS } \\
\text { 160414 } \\
\text { Indonesia } \\
\text { Ke Italia } \\
\text { Dengan } \\
\text { Sugeno }\end{array}$ \\
\hline Okt17 & 39,080 & 46,831 & 6,022 & 6.00 \\
\hline $\begin{array}{c}\text { Novem } \\
\text { ber } \\
2017\end{array}$ & 36,834 & 61,356 & 3,486 & 6.00 \\
\hline $\begin{array}{c}\text { Desem } \\
\text { ber } \\
2017\end{array}$ & 29,405 & 49,694 & 2,805 & 3.00 \\
\hline $\begin{array}{c}\text { Jan201 } \\
8\end{array}$ & 28,818 & 117,174 & 5,309 & 6.00 \\
\hline $\begin{array}{c}\text { Feb201 } \\
8\end{array}$ & 29,530 & 53,791 & 4,636 & 3.00 \\
\hline $\begin{array}{l}\text { Mar } \\
2018 \\
\end{array}$ & 32,286 & 80,821 & 4,757 & 6.00 \\
\hline $\begin{array}{c}\text { April20 } \\
18\end{array}$ & 29,598 & 75,478 & 2,864 & 6.00 \\
\hline $\begin{array}{c}\text { Mei } \\
2018\end{array}$ & 37,098 & 81,081 & 2,876 & 6.00 \\
\hline $\begin{array}{l}\text { Juni } \\
2018 \\
\end{array}$ & 20,519 & 73,322 & 3,542 & 3.00 \\
\hline $\begin{array}{c}\text { Juli } \\
2018\end{array}$ & 37,516 & 93,105 & 5,234 & 6.00 \\
\hline $\begin{array}{c}\text { Agustu } \\
\text { s } 2018\end{array}$ & 31,671 & 71,253 & 3,043 & 6.00 \\
\hline $\begin{array}{c}\text { Septem } \\
\text { ber } \\
2018\end{array}$ & 33,728 & 54,171 & 5,575 & 6.00 \\
\hline
\end{tabular}

Sumber: Rohimah (2019)

\section{KESIMPULAN}

Salah satu komiditi yang mempunyai nilai yang cukup tinggi dari sektor non migas salah satunya adalah ikan tuna olahan HS 160414. Dan salah satu negara tujuan utama ekspor ikan tuna olahan HS 160414 ada negara Italia. Untuk itu di perlukan suatu metode yang dapat digunakan dalam memprediksi jumlah optimal ekspor ikan tuna olahan HS 160414 ke Italia.

Metode yang dapat digunakan dalam optimalisasi jumlah ekspor ikan tuna olahan HS160414 ke Italia adalah dengan menggunakan metode Sugeno. Berdasarkan perhitungan diatas dari permintaan Italia pada bulan Juni 2018 sebesar \$20.519 dan total ekspor Indonesia untuk HS160414 sebesar \$73.332 didapat hasil Sugeno sebesar $\$ 3.000$.

Dari metode yang digunakan maka metode Sugeno yang mendapatkan hasil yang dekat dengan hasil sebenarnya dengan tingkat error $41.1 \%$, sehingga metode Sugeno bisa dijadikan metode yang direkomendasikan dalam optimalisasi jumlah optimal ekspor HS 160414 Indonesia ke Italia.

\section{REFERENSI}

Abrori, M., \& Prihamayu, A. H. (2015). Aplikasi Logika Fuzzy Mamdani dalam Pengambilan Keputusan Penentun Jumlah Produksi. Kaunia, XI(2), 91-99.

Iswari, L., \& Wahid, F. (2005). Alat Bantu Sistem Inferensi Fuzzy Metode Sugeno Orde Satu. In Seminar Nasional Aplikasi Teknologi Informasi 2005 (Vol. 2005, pp. 59-64).

Komariyah, S., Yunus, R. M., \& Rodiyansyah, S. F. (2016). Logika Fuzzy dalam Sistem Pengambilan Keputusan Penerimaan Beasiswa. Jurusan Teknik Informatika Fakultas Teknik Universitas Majalengka, 6169.

Kusumadewi, Sri dan Purnomo, Hari (2010). Aplikasi Logika Fuzzy Untuk Pendukung Keputusan. Yogyakarta: Graha Ilmu.

Mastur. (2006). Strategi Peningkatan Ekspor Indonesia dalam Perdagangan Bebas. AKSES: Jurnal Ekonomi Dan Bisnis, 1(1), 3145.

Rachman, I. (2013). Analisis Kinerja Ekspor Komoditi Perkebunan terhadap Pertumbuhan Ekonomi di Sulawesi Utara. EMBA, 1(3), 401-410.

Sedyaningrum, M., Suhadak, \& Nuzula, N. F. (2016). Pengaruh Jumlah Nilai Ekspor, Impor, dan Pertumbuhan Ekonomi terhadap Nilai Tukar dan Daya Beli Masyarakat di Indonesia. Jurnal 
Administrasi Bisnis (JAB), 34(1), 114-121.

Sulistiani, E., \& Noris, S. (2016). Penerapan FIS Metode Tsukamoto untuk Menentukan Kelayakan Pemberian Kredit. Jurnal Informatika Universitas Pamulang, 1(1), 2227.

Wachdani, R., Abidin, Z., \& Yaqin, M. A. (2012). Pengatur Pola Menu Makanan Balita untuk Mencapai Status Gizi Seimbang Menggunakan Sistem Inferensi Fuzzy Metode Sugeno. MATICS, 4(5).

Wardani, A. R., Nasution, Y. N., \& Amijaya, F. D. T. (2017). Aplikasi Logika Fuzzy dalam Mengoptimalkan Produksi Minyak Kelapa Sawit di PT. Waru Kaltim Plantation Menggunakan Metode Mamdani. Jurnal Informatika Mulawarman, 12(2), 94-103.

Wibowo, S. (2015). Penerapan Logika Fuzzy Dalam Penjadwalan Waktu Kuliah. Jurnal Informatika UPGRIS, 1(Juni), 59-77.

www.kemendag.go.id

www.trademap.org 